\title{
EFFECT OF THE COMBINATION OF VOLUNTARY EXERCISE AND DIETARY PROTEIN LEVELS ON THE DEPOSITION OF GLYCOGEN, LIVER AND SERUM LIPIDS IN MICE
}

\author{
Masanori YASHIRO and Shuichi KIMURA ${ }^{1}$ \\ Laboratory of Nutrition, Faculty of Agriculture, Tohoku University, \\ Sendai, Miyagi 980, Japan \\ (Received February 24, 1979)
}

\begin{abstract}
Summary The effects of voluntary exercise on the growth, glycogen of muscle and lipid contents of the liver and serum of mice fed different levels of dietary protein were investigated. In both the exercise and non-exercise groups, body weight gains were significantly greater in the $20 \%$ and $30 \%$ protein diet groups than in the $6 \%$ and $4 \%$ protein diet groups. After 6 weeks of age, it was shown that the amount of voluntary exercise by the $6 \%$ and $4 \%$ protein diet groups was greater than that by the $20 \%$ and $30 \%$ protein diet groups. As for hematological status, the raising of hemoglobin levels due to increasing dietary protein levels was further exaggerated by voluntary exercise. Hematocrit values rose with the increase in dietary protein levels. However the effect of exercise on hematocrit values was not clear. Liver glycogen levels, which were elevated with the increase in dietary protein levels, rose further due to exercise, though no changes were observed in muscle glycogen due to dietary protein levels and exercise.

The lipid contents of the liver in all groups tended to be lower in exercise groups compared with non-exercise groups and it was observed that the high levels of dietary protein depressed the increase in liver lipids. Liver triglyceride levels of all groups fed the dietary protein levels except for the $20 \%$ casein diet group decreased due to voluntary exercise, and liver triglyceride levels were also lowered as dietary protein levels increased. The levels of serum triglyceride of all groups decreased due to voluntary exercise. This phenomenon was most remarkable in rats fed a $6 \%$ casein diet. The tendency for serum cholesterol levels to decrease due to increasing dietary levels of protein was further intensified by voluntary exercise. However it was not further influenced by voluntary exercise in the $4 \%$ casein diet group.
\end{abstract}

Keywords voluntary exercise, dietary protein levels, physical fitness, endurance, glycogen, triglyceride, cholesterol

\footnotetext{
1 屋代正範, 木村修一
} 
In our previous investigation(1), it was shown that, when mice were permitted to exercise voluntarily, both animals fed a low protein-diet and a normal protein diet showed similar results in the growth and the development of organs, and that the amount of voluntary exercise was greater in the low-protein diet group than in the normal protein diet group.

It has been found that free fatty acids and glucose in the blood and glycogen of muscle and liver are the main sources of energy supply for exercise. TAYLOR et al. demonstrated that regular endurance exercise resulted in an increasing storage of glycogen in the skeletal muscle of humans $(2,3)$ and this phenomenon was also observed in rats (4). This increased storage of glycogen may act as a factor to increase endurance (5). It seems to be an indication of physical fitness.

Many investigations concerning the effects of exercise on serum and liver lipids have been reported from a preventive point of view, for instance hyperlipemia and atherosclerosis, with regard to the relationship between exercise and health $(6,7,26$, 27). MoRris and HeADY (8) suggested that physical activity in work is associated with a lower incidence of coronary heart disease in middle-aged men. Further, it is known that dietary protein levels have an effect on liver lipids and blood cholesterol levels. Namely, decreasing the level of dietary protein results in increased plasma and liver cholesterol and liver fat levels $(9,30)$. So far it is known that exercise causes a reduction in the level of plasma lipids $(6,7)$. But there are few reports concerned with the effect of a combination of exercise and dietary protein levels on plasma and liver lipids.

The purpose of the present investigation was to examine the effect of the combination of voluntary exercise and dietary protein levels on the glycogen storage capacity of the liver and skeletal muscle, and on the liver and serum lipids of male mice.

\section{EXPERIMENTAL}

Animals and diets. Weaning, male JCL:ICR mice (Japan Clea Inc., Tokyo), weighing 10 to $12 \mathrm{~g}$, were used in this experiment. The experimental diets are shown in Table 1 . All mice were housed individually in wire net cages and fed a $20 \%$ casein diet for one week. After this period, they were divided into eight groups, designated non-exercise group $(30 \% \mathrm{NE})$ or exercise group $(30 \% \mathrm{E})$ on a $30 \%$ casein diet, nonexercise group $(20 \% \mathrm{NE})$ or exercise group $(20 \% \mathrm{E})$ on a $20 \%$ casein diet, nonexercise group $(6 \% \mathrm{NE})$ or exercise group $(6 \% \mathrm{E})$ on a $6 \%$ casein diet and nonexercise group $(4 \%$ NE) or exercise group $(4 \%$ E) on a $4 \%$ casein diet. The number of mice in each group was ten. All exercise groups were housed individually in wire net cages with a revolving treadwheel. The animals were kept individually on the experimental diets for about 120 days. Throughout the experiment, fresh diet and water were supplied ad libitum. Lighting was regulated to provide $12 \mathrm{hr}$ of light from $8: 00$ a.m. to $8: 00$ p.m. and $12 \mathrm{hr}$ of darkness from 8:00 p.m. to 8:00 a.m. Room temperature was maintained at $24^{\circ} \mathrm{C} \pm 1{ }^{\circ} \mathrm{C}$. 
Table 1. Diet composition.

\begin{tabular}{|c|c|c|c|c|}
\hline & \multicolumn{4}{|c|}{ Diet } \\
\hline & $4 \%$ casein & $6 \%$ casein & $20 \%$ casein & $30 \%$ casein \\
\hline & \multicolumn{4}{|c|}{ (g/100g diet $)$} \\
\hline Potato starch & 85 & 83 & 69 & 59 \\
\hline Soybean oil & 5 & 5 & 5 & 5 \\
\hline Casein & 4 & 6 & 20 & 30 \\
\hline Salt mixture ${ }^{a}$ & 4 & 4 & 4 & 4 \\
\hline $\begin{array}{l}\text { Water-soluble } \\
\text { vitamin mixture }^{\mathfrak{b}}\end{array}$ & 1 & 1 & 1 & 1 \\
\hline $\begin{array}{l}\text { Fat-soluble } \\
\text { vitamin mixture }^{c}\end{array}$ & 0.8 & 0.8 & 0.8 & 0.8 \\
\hline Cholin chloride & 0.2 & 0.2 & 0.2 & 0.2 \\
\hline
\end{tabular}

a Harper's salt mixture purchased from Oriental Yeast Co., Ltd.

b Harper's water-soluble vitamin mixture purchased from Oriental Yeast Co., Ltd.

c Fat-soluble vitamin mixture: vitamin A, 1,000 IU/100 g diet, vitamin D, $100 \mathrm{IU} / 100 \mathrm{~g}$ diet, vitamin $\mathrm{E}, 10 \mathrm{mg} / 100 \mathrm{~g}$ diet.

Measurement of the amount of voluntary exercise. The revolving treadwheel (circumference: $44 \mathrm{~cm}$, width: $6 \mathrm{~cm}$ ) allowed the animals to exercise voluntarily. The amount of voluntary exercise (running distance) was measured by an electromagnetic counter which records the number of rotations of the revolving treadwheel.

Sampling of the organs, tissues and blood. All mice were deprived of food for $10 \mathrm{hr}$ and then killed by dissection of the carotid artery. Blood was immediately collected in a test tube. Then, the heart, lung, liver, kidneys, spleen, epididymal fat tissue and gastrocnemius muscle were removed and weighed. Serum was prepared by a routine method and was submitted to analyses for triglyceride and cholesterol.

Chemical analysis. Hemoglobin was measured by the Hemoglobin-Test, which was purchased from Wako Pure Chemical Industries, Ltd. Hematocrit values were determined by the centrifugation method. Mitochondria were prepared from gastrocnemius muscle as described by Holloszy (10) and, for the determination of mitochondrial proteins, the procedure of CLELAND and SLATER (11) was used. Protein was determined by the Biuret method (12). The determinations of glycogen in the liver and gastrocnemius muscle were undertaken as described by Lo et al. (13). The total lipids of the liver were measured by the method of FoLCH et al. (14). Liver and serum triglyceride were determined by the modified method of VAN HANDELKAWADE (15). Serum cholesterol was determined by the Cholesterol B-Test (Wako Pure Chemical Industries, Ltd.). The significance of the results was analyzed by the student's " $t$ " test and $2 \times 4$ factorial analysis of variance (16). 
RESULTS

The effects of voluntary exercise on the weight gains of mice fed different levels of dietary protein

As shown in Fig. 1, after 6 weeks of age, body weight gains of the $30 \%$ and $20 \%$ casein diet groups were significantly greater than those of the $6 \%$ and $4 \%$ casein diet groups. There was also a significant difference between the $6 \%$ and $4 \%$ casein diet groups. The weight gains of the $4 \%$ casein diet groups were slight. Significant differences in body weight gains were found between non-exercise and exercise groups after 14 weeks of age for the $30 \%$ and $20 \%$ casein diet groups. However, no clear differences were seen between non-exercise and exercise groups in low-protein diet groups.

\section{Amount of voluntary exercise of mice fed different levels of dietary protein}

The results are shown in Fig. 2. After 6 weeks of age, running distances were remarkably longer in the $4 \%$ and $6 \%$ E groups than in the $20 \%$ and $30 \%$ E groups. Notably, it was observed that running distances of about $6,000 \mathrm{~m}$ per day were obtained in the $6 \%$ E group at 15 weeks of age.

\section{The effect of voluntary exercise on food intake}

Table 2 shows the average daily food intake. During the experimental period, the food intake of all groups tended to be larger in exercise groups than in nonexercise groups. Especially, that of the $30 \%$ E group was significantly larger than

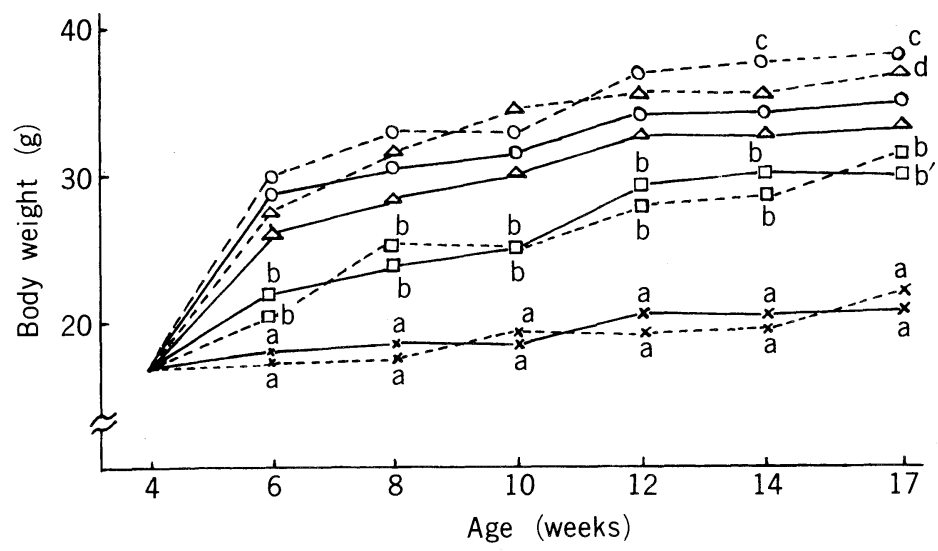

Fig. 1. The growth curves of exercised and non-exercised mice fed four levels of dietary protein. $\bigcirc$, $30 \%$ casein diet group; $\triangle, 20 \%$ casein diet group; $\square, 6 \%$ casein diet group; $\times, 4 \%$ casein diet group; ------, non exercise group; -

Between $4 \% \mathrm{NE}(\mathrm{E})$ and $6 \%, 20 \%, 30 \% \mathrm{NE}(\mathrm{E})$; a, $p<0.01$.

Between $6 \% \mathrm{NE}(\mathrm{E})$ and $20 \%, 30 \%$, NE(E); b, $p<0.01$, b $p<0.05$.

Between $30 \% \mathrm{NE}$ and $30 \% \mathrm{E} ; \mathrm{c}, p<0.05$.

Between $20 \% \mathrm{NE}$ and $20 \% \mathrm{E} ; \mathrm{d}, p<0.05$. 


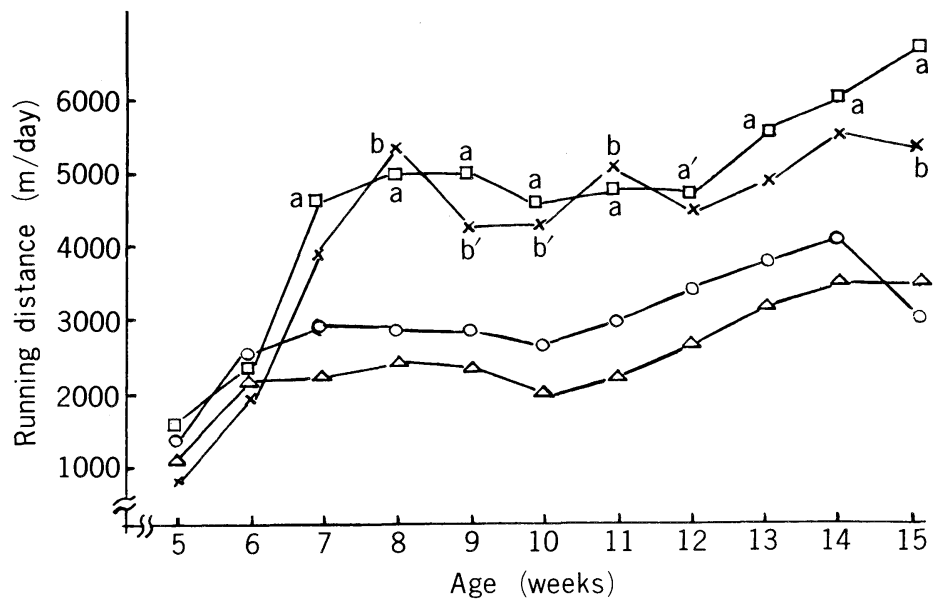

Fig. 2. The amount of voluntary exercise of mice fed four levels of dietary protein. $\bigcirc, 30 \%$ casein diet group; $\triangle, 20 \%$ casein diet group; $\square, 6 \%$ casein diet group; $\times, 4 \%$ casein diet group.

a, Between $6 \%$ and $20 \%$ or $30 \%$

b, Between $4 \%$ and $20 \%$ or $30 \%$

$\mathrm{a}^{\prime}$, Between $6 \%$ and $20 \%$

$b^{\prime}$, Between $4 \%$ and $20 \%$

\}$p<0.05$

that of the $30 \%$ NE group $(p<0.05)$. Food intake of the $4 \%$ NE group was significantly lower compared with that of the $20 \% \mathrm{NE}$ and $30 \% \mathrm{NE}$ groups $(4 \% \mathrm{NE}$ vs $20 \%$ and $30 \% \mathrm{NE} ; p<0.01$ ) and that of the $6 \%, 20 \%$ and $30 \%$ E groups was significantly larger than that of the $4 \%$ E group $(4 \% \mathrm{E}$ vs $6 \%$ and $20 \% \mathrm{E} ; p<0.05$, and $4 \%$ E vs $30 \% \mathrm{E} ; p<0.01$ ).

\section{The effect of voluntary exercise on organ and tissue weights}

As shown in Table 3, in all groups, absolute weight and weight per $100 \mathrm{~g}$ of body weight of the heart, lung, spleen, liver and testes tended to be heavier in exercise groups than in non-exercise groups. Epididymal fat tissues of exercise groups were remarkably less than those of non-exercise groups. The gastrocnemius muscle of exercise groups had a tendency to be heavier than that of non-exercise groups.

Factorial analysis of variance for organs and tissues

The results are shown in Table 4 . Organs and tissues were analyzed by $2 \times 4$ factorial analysis (two factors of exercise and non-exercise, and four factors of dietary protein levels) of variance. In these calculations, it was found that the final body weights and the weights of the heart, lung, liver, spleen, testes and epididymal fat tissue were significantly changed by exercise and dietary protein levels. For the kidneys, an interaction was found between the factors of exercise and dietary protein levels. The gastrocnemius muscle was affected by exercise. 
Table 2. Effect of voluntary exercise on food intake of mice fed four levels of dietary protein.

\begin{tabular}{|c|c|c|c|}
\hline Group & $\begin{array}{c}\text { Initial } \\
\text { body } \\
\text { weight }(\mathrm{g})\end{array}$ & $\begin{array}{c}\text { Final } \\
\text { body } \\
\text { weight }(\mathrm{g})\end{array}$ & $\begin{array}{l}\text { Average daily } \\
\text { food } \\
\text { intake (g) }\end{array}$ \\
\hline $4 \% \frac{\mathrm{NE}}{\mathrm{E}}$ & $\begin{array}{l}16.8 \pm 0.6(10) \\
16.7 \pm 0.4(10)\end{array}$ & $\begin{array}{l}22.4 \pm 1.2^{\mathrm{b}}(8) \\
21.6 \pm 1.1^{\mathrm{b}}(8)\end{array}$ & $\begin{array}{l}4.2 \pm 0.2^{\mathrm{c}}(8) \\
4.7 \pm \pm 0.2^{\mathrm{f}, \mathrm{g}}(8)\end{array}$ \\
\hline $6 \% \mathrm{NE}$ & $\begin{array}{l}16.6 \pm 0.5(10) \\
17.0 \pm 0.3(10)\end{array}$ & $\begin{array}{l}30.9 \pm 1.2^{\mathrm{d}}(8) \\
29.2 \pm 0.6^{\mathrm{e}}(10)\end{array}$ & $\begin{array}{l}5.0 \pm 0.3 \quad(8) \\
5.6 \pm 0.2(8)\end{array}$ \\
\hline $20 \% \frac{\mathrm{NE}}{\mathrm{E}}$ & $\begin{array}{l}17.0 \pm 0.5(10) \\
17.7 \pm 0.4(10)\end{array}$ & $\begin{array}{l}36.2 \pm 1.0^{\mathrm{a}}(10) \\
32.3 \pm 0.9(10)\end{array}$ & $\begin{array}{l}5.3 \pm 0.2 \quad(8) \\
5.6 \pm 0.2(8)\end{array}$ \\
\hline $30 \% \mathrm{NE}$ & $\begin{array}{l}17.0 \pm 0.5(10) \\
16.9 \pm 0.3(10)\end{array}$ & $\begin{array}{l}36.4 \pm 0.7^{\mathrm{a}}(8) \\
33.0 \pm 0.8\end{array}$ & $\begin{array}{l}5.1 \pm 0.2 \quad(8) \\
6.2 \pm 0.5^{\mathrm{a}}(8)\end{array}$ \\
\hline
\end{tabular}

$4 \% \mathrm{NE}, 4 \%$ casein diet non-exercise group; $4 \% \mathrm{E}, 4 \%$ casein diet exercise group. $6 \% \mathrm{NE}, 6 \%$ casein diet non-exercise group; $6 \% \mathrm{E}, 6 \%$ casein diet exercise group. $20 \% \mathrm{NE}, 20 \%$ casein diet non-exercise group; $20 \% \mathrm{E}, 20 \%$ casein diet exercise group. $30 \% \mathrm{NE}, 30 \%$ casein diet non-exercise group; $30 \% \mathrm{E} ; 30 \%$ casein diet exercise group.

${ }^{\text {a }} p<0.05$ Between non-exercise and exercise groups.

b $p<0.01$ Between $4 \%$ NE (E) and $6 \%, 20 \%$ or $30 \%$ NE (E) groups.

c $p<0.01$ Between $4 \% \mathrm{NE}$ and $20 \%$ or $30 \% \mathrm{NE}$ groups.

d $p<0.01$ Between $6 \%$ NE and $20 \%$ or $30 \%$ NE groups.

e $p<0.05$ Between $6 \%$ E and $20 \%$ or $30 \%$ NE groups.

f $p<0.05$ Between $4 \% \mathrm{E}$ and $6 \%$ or $20 \%$ E groups.

g $p<0.01$ Between $4 \% \mathrm{E}$ and $30 \% \mathrm{E}$ groups.

Number of mice is in parentheses.

Values are means $\pm \mathrm{SE}$.

Hematological status, mitochondrial protein of muscle and glycogen contents of muscle and liver

As shown in Table 5, hemoglobin values of all groups tended to be increased by exercise. Especially, when hemoglobin values of the 4\% $\mathrm{E}$ and $6 \% \mathrm{E}$ groups were compared with those of the $4 \% \mathrm{NE}$ and $6 \% \mathrm{NE}$ groups, respectively, there were significant differences $(4 \% \mathrm{NE}$ vs $4 \% \mathrm{E} ; p<0.01$ and $6 \% \mathrm{NE} v s 6 \mathrm{E} ; p<0.05)$. Values for the $4 \% \mathrm{NE}$ group were significantly lower than those of the $30 \% \mathrm{NE}$ group $(p<0.05)$. Hematocrit values were significantly lower for the $4 \%$ and $6 \% \mathrm{NE}$ groups as compared with the $30 \%$ NE group $(4 \% \mathrm{NE}$ vs $30 \% \mathrm{NE} ; p<0.01$ and $6 \%$ $\mathrm{NE}$ vs $30 \% \mathrm{NE} ; p<0.05)$. Thus, it was observed that hematocrit values were elevated with increasing levels of dietary protein, but they were not affected by exercise. In all groups, mitochondrial protein of muscle tissue showed a tendency to increase in exercise groups over non-exercise group levels. Notably, the $4 \%$ E, $6 \%$ E and $20 \% \mathrm{E}$ groups had significantly high contents as compared with the $4 \% \mathrm{NE}, 6 \% \mathrm{NE}$ and $20 \%$ NE groups $(4 \%$ NE $v s 4 \% \mathrm{E} ; p<0.05,6 \%$ NE $v s 6 \% \mathrm{E} ; p<0.01$ and $20 \% \mathrm{NE} v s$ 


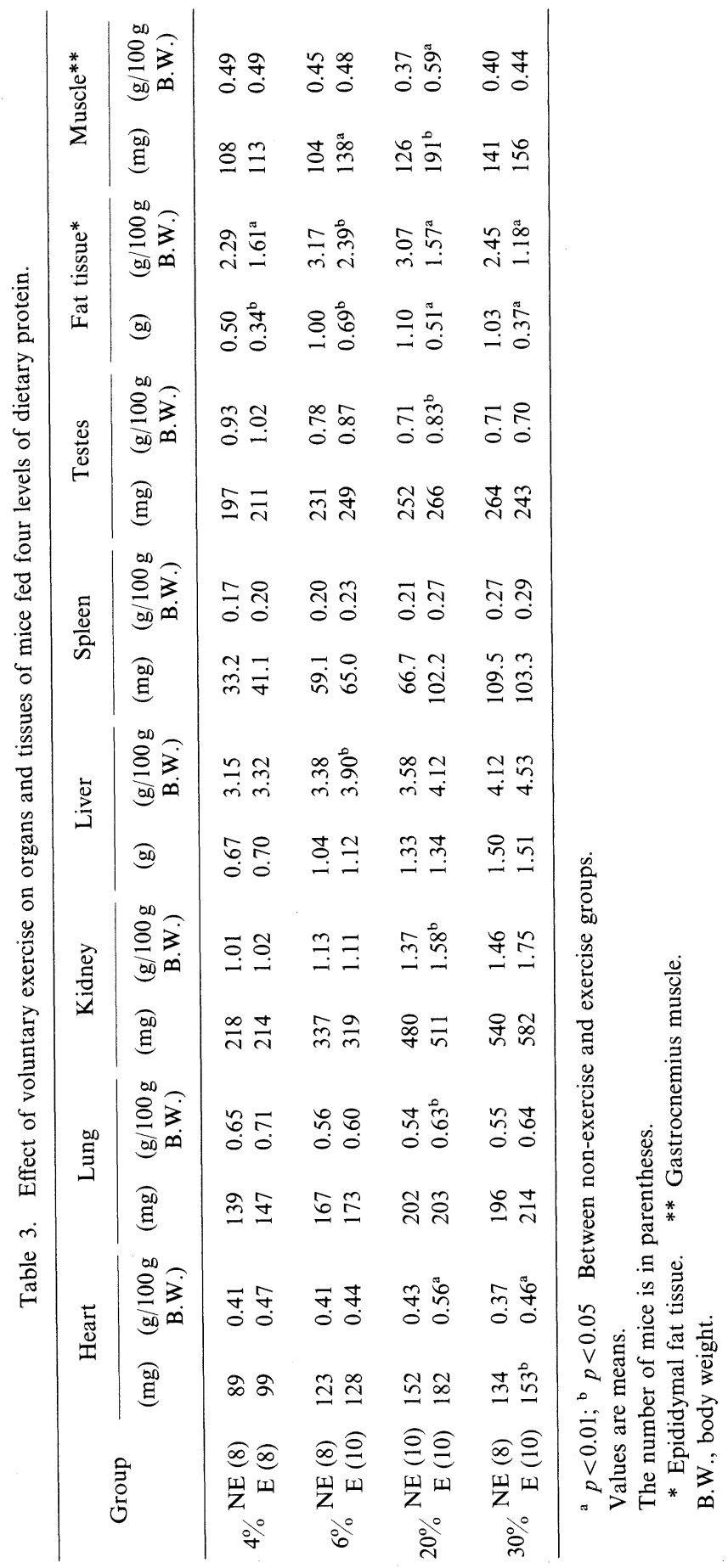




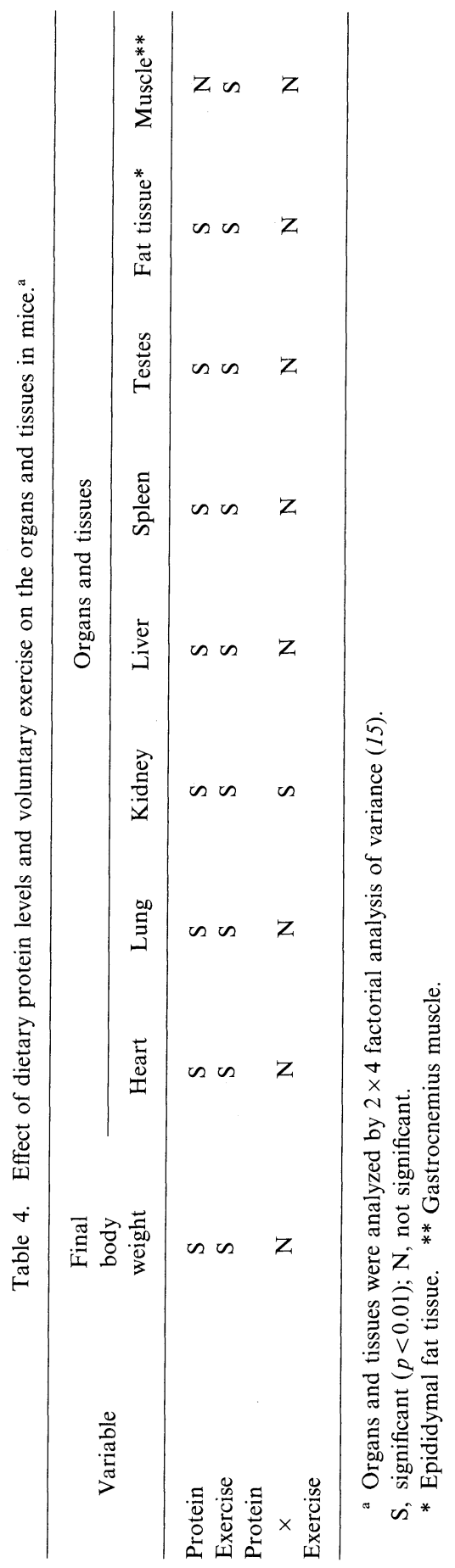


Table 5. Effect of voluntary exercise on hematological status, mitochondrial protein of the muscle and glycogen contents of muscle and liver in mice fed four levels of dietary protein.

\begin{tabular}{|c|c|c|c|c|c|}
\hline \multirow{2}{*}{ Group } & \multicolumn{2}{|c|}{ Hematological status } & \multirow{2}{*}{$\begin{array}{l}\text { Mt protein } \\
\text { of muscle } \\
\text { (mg/g tissue) }\end{array}$} & \multicolumn{2}{|c|}{ Glycogen* } \\
\hline & $\begin{array}{l}\text { Hemoglobin } \\
(\mathrm{g} / 100 \mathrm{ml})\end{array}$ & $\begin{array}{l}\text { Hematocrit } \\
(\%)\end{array}$ & & $\begin{array}{c}\text { Muscle } \\
\text { (mg/g tissue) }\end{array}$ & $\begin{array}{c}\text { Liver } \\
\text { (mg/g tissue) }\end{array}$ \\
\hline \multirow{2}{*}{$4 \% \begin{array}{r}\mathrm{NE} \\
\mathrm{E}\end{array}$} & $15.7 \pm 0.5(7)$ & $38.9 \pm 1.1(8)$ & $4.37 \pm 0.24(8)$ & $0.23 \pm 0.03(8)$ & $0.57 \pm 0.03$ \\
\hline & $18.2 \pm 0.5^{\mathrm{a}}(7)$ & $40.7 \pm 0.8$ & $5.83 \pm 0.56^{\mathrm{b}}(8)$ & $0.29 \pm 0.02(7)$ & $4.79 \pm 0.91^{\mathrm{a}}(7)$ \\
\hline \multirow{2}{*}{$6 \% \begin{array}{r}\mathrm{NE} \\
\mathrm{E}\end{array}$} & $15.8 \pm 0.7(7)$ & $40.6 \pm 0.7(7)$ & $4.46 \pm 0.42(8)$ & $0.23 \pm 0.02(7)$ & $0.76 \pm 0.07(7)$ \\
\hline & $19.1 \pm 0.4^{\mathrm{b}}(8)$ & $41.8 \pm 0.5(9)$ & $6.13 \pm 0.36^{\mathrm{a}}(9)$ & $0.31 \pm 0.03$ & $9.12 \pm 0.92^{\mathrm{a}}(8)$ \\
\hline \multirow{2}{*}{$20 \% \quad \mathrm{NE}$} & $16.7 \pm 0.4(9)$ & $41.6 \pm 0.7(8)$ & $4.09 \pm 0.28$ & $0.33 \pm 0.04$ & $0.90 \pm 0.18$ \\
\hline & $17.6 \pm 0.4$ & $41.9 \pm 0.7(8)$ & $5.98 \pm 0.31^{\mathrm{a}}(8)$ & $0.27 \pm 0.01$ & $5.57 \pm 0.65^{\mathrm{a}}(7)$ \\
\hline \multirow{2}{*}{$30 \% \frac{\mathrm{NE}}{\mathrm{E}}$} & $18.3 \pm 0.6(7)$ & $43.7 \pm 1.0(7)$ & $4.60 \pm 0.32(8)$ & $0.24 \pm 0.02(8)$ & $4.00 \pm 0.84(8)$ \\
\hline & $18.4 \pm 0.7$ & $44.0 \pm 1.1(8)$ & $5.23 \pm 0.49(8)$ & $0.32 \pm 0.03$ & $8.13 \pm 0.87^{\mathrm{a}}(7)$ \\
\hline
\end{tabular}

${ }^{\mathrm{a}} p<0.01 ;{ }^{\mathrm{b}} p<0.05$ Between non-exercise and exercise groups. Values are mean $\pm \mathrm{SE}$.

The number of mice is in parenthesis. Mt, mitochondrial.

* Glycogen contents in the muscle and liver were lowered by $10 \mathrm{hr}$ ' food deprivation before sacrifice.

$20 \% \mathrm{E} ; p<0.01)$. No differences in mitochondrial protein of muscle between lowprotein diet groups and normal or high-protein diet groups could be seen.

Liver glycogen levels of all groups were markedly higher in exercise groups than in non-exercise groups $(p<0.01)$ and such levels tended to be elevated as dietary protein levels increased. On the other hand, no effects of exercise and dietary protein levels on muscle glycogen were observed.

\section{Liver and serum lipids}

The results are shown in Table 6. In all groups, total lipid contents of the liver showed a tendency to decrease with increasing levels of dietary protein; when total liver lipids of the $30 \%$ NE group were compared with those of the $4 \%$ NE and $6 \%$ $\mathrm{NE}$ groups, respectively, the $30 \%$ NE group was found to have a significantly lower level $(30 \%$ NE $v s 4 \% \mathrm{NE} ; p<0.01$ and $30 \%$ NE $v s 6 \% \mathrm{NE} ; p<0.05)$. The levels of total liver lipids of all groups tended to decrease with exercise and liver triglyceride levels of all groups, except that the $20 \%$ casein diet group was lower in exercise groups than in non-exercise groups. There was a significant difference between the $4 \% \mathrm{E}$ and $4 \% \mathrm{NE}$ groups $(p<0.05)$. Liver triglyceride levels increased as dietary protein levels decreased; the liver triglyceride level of the $4 \%$ NE group was significantly higher than that of the $30 \%$ NE group $(p<0.05)$. 
Table 6. Effect of voluntary exercise on the lipid contents of liver and serum lipids of mice fed four levels of dietary protein.

\begin{tabular}{|c|c|c|c|c|c|}
\hline \multirow[b]{2}{*}{ Group } & \multirow{2}{*}{$\begin{array}{l}\text { Liver weight } \\
\text { (g) }\end{array}$} & \multicolumn{2}{|c|}{ Liver } & \multicolumn{2}{|c|}{ Serum } \\
\hline & & $\begin{array}{l}\text { Total lipids } \\
\text { (mg/g tissue) }\end{array}$ & $\begin{array}{l}\text { Triglyceride } \\
\text { (mg/g tissue) }\end{array}$ & $\begin{array}{l}\text { Triglyceride } \\
(\mathrm{mg} / 100 \mathrm{ml})\end{array}$ & $\begin{array}{l}\text { Cholesterol } \\
(\mathrm{mg} / 100 \mathrm{ml})\end{array}$ \\
\hline $\mathrm{NE}$ & $0.67 \pm 0.11$ & $39.7 \pm 1.7(8)$ & $6.18 \pm 0.49(7)$ & $46.3 \pm 3.4(7)$ & $202.7 \pm 10.7(7)$ \\
\hline $4 \% \quad E$ & $0.70 \pm 0.16(8)$ & $37.1 \pm 2.4(7)$ & $3.49 \pm 0.42^{b}(7)$ & $37.3 \pm 1.5(6)$ & $218.2 \pm 10.6(7)$ \\
\hline 6E & $1.04 \pm 0.13$ & $35.9 \pm 1.7(7)$ & $5.31 \pm 0.59(7)$ & $42.5 \pm 3.0(7)$ & $186.3 \pm 7.1(7)$ \\
\hline $6 \% \quad \mathrm{E}$ & $1.12 \pm 0.11$ & $31.9 \pm 2.7(8)$ & $3.73 \pm 0.27(8)$ & $24.4 \pm 1.5^{\mathrm{a}}(7)$ & $167.1 \pm 6.0(7)$ \\
\hline $20^{\circ} \mathrm{NE}$ & $1.33 \pm 0.21(10)$ & $36.4 \pm 1.7(5)$ & $4.41 \pm 0.91$ & $35.4 \pm 2.3(7)$ & $171.5 \pm 10.2(6)$ \\
\hline $20 \% \quad \mathrm{E}$ & $1.34 \pm 0.29(10)$ & $31.2 \pm 2.5(5)$ & $4.74 \pm 0.77$ (4) & $29.1 \pm 2.0(7)$ & $159.1 \pm 9.0(7)$ \\
\hline NE & $1.50 \pm 0.11(8)$ & $27.1 \pm 1.8(7)$ & $3.28 \pm 0.35(8)$ & $42.7 \pm 3.5(7)$ & $167.9 \pm 8.1(7)$ \\
\hline $30 \% \quad \mathrm{E}$ & $1.51 \pm 0.12(10)$ & $26.3 \pm 1.5(8)$ & $2.24 \pm 0.18(9)$ & $35.6 \pm 2.3(7)$ & $108.4 \pm 8.1^{b}(8)$ \\
\hline
\end{tabular}

${ }^{\mathrm{a}} p<0.01 ;{ }^{\mathrm{b}} p<0.05 \quad$ Between non-exercise and exercise groups.

Values are mean $\pm \mathrm{SE}$.

The number of mice is in parentheses.

Serum triglyceride of exercise groups showed lower levels as compared with those of non-exercise groups. Notably, a significant difference between the $6 \% \mathrm{E}$ and $6 \%$ NE groups could be seen. A tendency for serum cholesterol levels to decrease with exercise was observed. Serum cholesterol of the $30 \%$ E group was markedly lower than that of the $30 \% \mathrm{NE}$ group $(p<0.05)$. However, it is interesting that no effect of exercise was observed in the $4 \%$ casein diet group. Serum cholesterol levels tended to be elevated with decreasing levels of dietary protein.

Factorial analysis of variance for hematological status, glycogen contents, liver and serum lipids, etc.

Table 7 shows the results of factorial analysis of variance. Hematocrit and hemoglobin values were influenced by dietary protein levels irrespective of exercise. There are interactions in hemoglobin values between the factors of dietary protein levels and exercise. Mitochondrial protein of muscle was altered by exercise. Liver glycogen levels, total lipids, triglyceride and serum cholestreol were changed by dietary protein levels regardless of exercise. Significant changes in liver glycogen, total lipids, triglyceride, serum triglyceride and cholesterol were brought about by exercise independent of dietary protein levels. Interactions between dietary protein levels and exercise were observed with regard to liver triglyceride and serum cholesterol. 


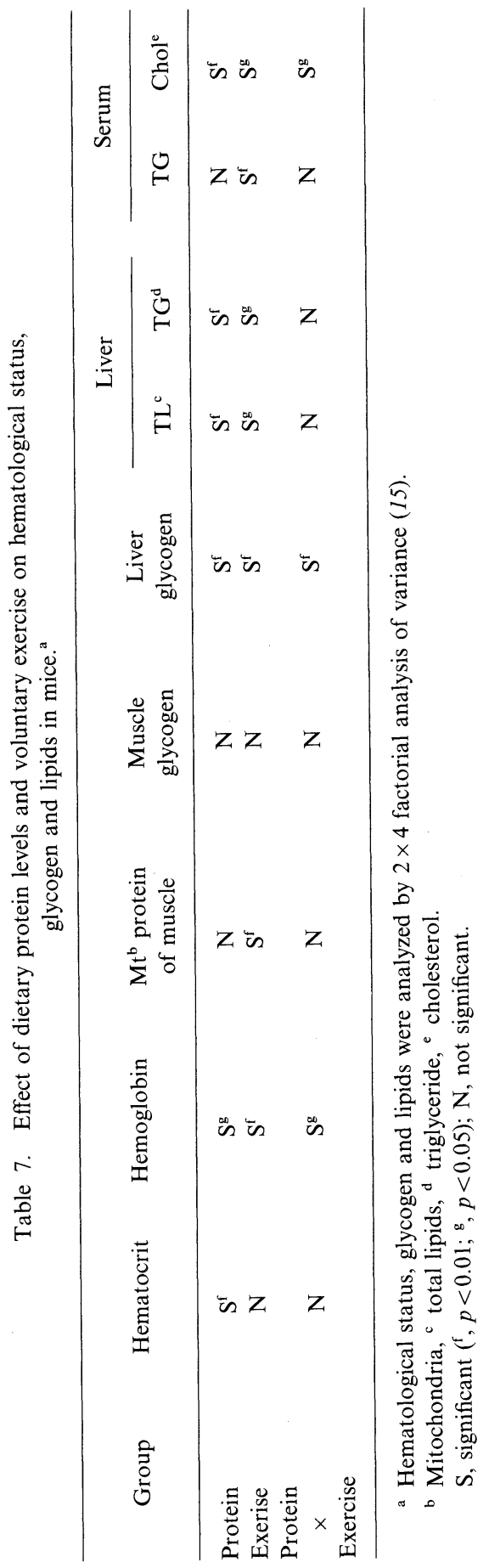




\section{DISCUSSION}

In the present investigation, it was observed that body weight gains of the $30 \%$ and $20 \%$ NE groups were greater than those of the $30 \%$ and $20 \% \mathrm{E}$ groups. This result is in agreement with that of our previous study. As for the reason for reduced body weight gains in exercise groups, it is thought that the deposition of fat was less because the consumption of calories increased with exercise. On the other hand, there was no difference in the body weight gains of low-protein diet groups. This may be due to the fact that the proportion of loss of adipose tissue was less in lowprotein diet groups than in normal and high-protein diet groups.

As mentioned in RESULTS, the running distances of low-protein diet groups were markedly longer than those of normal and high-protein diet groups. This result in the present study corresponds to those in our previous investigation and to those in a study by FugE et al.(17). The longer running distances of low-protein diet groups may be due to more rapid diffusion of lactate out of the muscles (17), the increased capacity of exercise-adapted muscles to oxidize fatty acids (5) and the lower body weight of animals fed low-protein diets (17), etc.

Consolazio et al. (18) and SAKAmOTO et al. (19) found that, in humans and rats fed low-protein diets, hemoglobin and hematocrit values showed lower levels as campared with those of high- and normal protein diet groups. The present experiment showed similar results. Hemoglobin values of exercise groups tended to be higher than those of non-exercise groups. Notably, those of the $4 \%$ and $6 \% \mathrm{E}$ groups were significantly higher than those of the $4 \%$ and $6 \%$ NE groups. Generally, it is known that hemoglobin plays an important role as a carrier of oxygen. Accordingly, in the present study, the adaptation to voluntary exercise of exercise group animals may bring about an elevation of hemoglobin; furthermore, a clearer increase in hemoglobin may be found in low-protein diet groups because the amount of voluntary exercise of the $4 \%$ and $6 \%$ E groups was considerably greater than that of the $20 \%$ and $30 \%$ E groups.

The present experimental results showed that exercise groups had higher liver glycogen levels than those of non-exercise groups. Plasma free fatty acids, blood glucose, muscle and liver glycogen are used as energy sources in exercise. HicKsON et al. (5) noted that increased availability of fatty acids could increase endurance by slowing the rate of glycogen depletion. There is also strong evidence that endurance can be increased by raising, and diminished by lowering, body carbohydrate stores $(20,21)$. Therefore, it is expected that the $6 \%$ E group, which had the highest content of liver glycogen, will have greater endurance in relation to the largest amount of voluntary exercise. Muscle glycogen content of exercise groups tended to be higher than non-exercise groups, but the differences were not statistically significant.

Although no definitive evidence exists, it appears reasonable to assume that the difference in mitochondrial mass is related to the higher contractile force of tissues and the associated increased need for energy supply (22). Holloszy (10) noted that 
an increase in the number and the size of mitochondria of muscles of exercised animals must have occurred. In the present investigation, it was also observed that muscle mitochondrial proteins increased in exercise groups as compared with nonexercise groups.

The facts described above suggest the possibility that animals fed low-protein diets may be brought to about the same level of physical fitness as high- or normal dietary protein groups by voluntary exercise.

Previously, many studies of the effect of exercise on serum and liver lipids have been published. SАкамото et al. $(19,23)$ reported that feeding low-protein diets to rats resulted in an accumulation of lipids in the liver. An increase in total lipids and triglyceride in the liver of mice fed low-protein diets was also observed in the present investigation. On the other hand, it appeared likely that, generally, this increase in lipids is diminished by voluntary exercise. FUKUDA et al. (7) reported that the effects of running on liver lipid levels were not uniform, but, in the data presented in this report, liver triglyceride of all groups except the $20 \%$ casein diet group tended to decrease with voluntary exercise. An especially clear difference in liver triglyceride could be seen between the 4\% NE and 4\% E groups. ENwONwU et al. (24) reported that histological evaluation of livers from protein-calorie-deficient animals showed extensive fatty metamorphosis and loss of cytoplasmic basophilia. The present experimental data suggest the possibility that impairment of the liver of mice fed the $4 \%$ casein diet might be prevented to some extent by voluntary exercise. The discrepancy with the results of FuKUDA et al. (7) may be due to differences in the amount of exercise and in the experimental conditions.

It has been reported that exercise causes a reduction in the concentration of plasma lipids $(6,7,25,26)$. The present investigation also showed that serum triglyceride and cholestrol tended to decrease with voluntary exercise. Serum triglyceride levels of the $6 \%$ E group were significantly lower than those of the $6 \%$ NE group. The cause of this diminution may be attributed to lowering of serum very-low-density lipoprotein and low-density lipoprotein due to exercise (27). Because of differences in experimental conditions and species differences, etc., certain results have not always been consistent with regard to the effect of dietary protein levels on the concentration of cholesterol. Namely, it has been reported that the concentration of plasma cholesterol is increased by increasing the dietary protein levels (28); conversely, a negative relationship between dietary protein levels and plasma cholesterol exists $(9,29)$. In the present investigation, it was found that serum cholesterol levels diminished with increasing levels of dietary protein. This result is in agreement with the report of LEVEILLE et al. (9). The mechanism by which increased dietary protein depresses plasma cholesterol levels is not clear. NISHIDA et al. (29) presented evidence indicating that serum cholesterol depression observed in chicks fed a high-protein diet was the result of a decrease in cholesterol synthesis and an increased conversion of cholesterol to bile acids. The data presented in the current report showed that serum cholesterol levels of all groups except the $4 \%$ casein diet group tended to decrease with voluntary exercise; in particular, the 
cholesterol level of the $30 \%$ E group was significantly lower than that of the $30 \% \mathrm{NE}$ group. It is suggested that the cause of lower cholesterol levels in exercise groups may be due predominantly to changes in the metabolism of serum high-density lipoprotein (27). It is known that physical exercise result in accelerated oxidation of cholesterol and increased excretion of sterol in feces $(30,31)$. Therefore, it is supposed that serum cholesterol levels of the exercise groups in the present experiment might have been diminished by the interaction of oxidation and excretion of cholesterol. The fact that the cholesterol level of the $4 \%$ casein diet group did not decrease due to exercise might be attributed to a decrease in the activity of the lecithin-cholesterol acyltransferase (LCAT) by impairment of liver tissue (32).

The present results have shown that an increase in lipids in the liver and serum is easily brought about in animals fed low-protein diets. The increase in the concentration of lipids of the liver and serum due to decreasing levels of dietary protein tended to be depressed by voluntary exercise, but such an effect was not observed in serum cholesterol of animals fed a severe protein-deficient diet.

In addition to research on metabolic changes of serum lipoprotein, further study is necessary to elucidate the mechanisms by which dietary protein and physical exercise depress serum cholesterol levels.

We thank Mr. Junichi Suwa for his expert technical assistance in the making of an electro-magnetic counter.

\section{REFERENCES}

1) Yashiro, M., and Kimura, S. (1979): Effect of voluntary exercise on physiological function and feeding behavior of mice on a $20 \%$ casein diet or a $10 \%$ casein diet. J. Nutr. Sci. Vitaminol., 25, $23-32$.

2) TAYlor, A. W., LAPPAGE, R., and RAO, S. (1971): Skeletal muscle glycogen stores after submaximal and maximal work. Med. Sci. Sports, 3, 75-78.

3) TAYlor, A. W., Thayer, R., and RaO, S. (1972): Human skeletal muscle glycogen synthetase activities with exercise and training. Can. J. Physiol. Pharm., 50, 411-415.

4) Taylor, A. W., Cary, S., Mcnulty, M., Garrod, J., and Secord, D. C. (1974): Effects of food restriction and exercise upon the deposition and mobilization of energy stores in the rat. J. Nutr., 104, 218-222.

5) Hickson, R. C., Rennie, M. J., Conlec, R. K., Winder, W. W., Holloszy, J. O. (1977): Effects of increased plasma fatty acids on glycogen utilization and endurance. J. Appl. Physiol., 43, 829-833.

6) Fukuda, N., Hori, K., and Sugano, M. (1976): Effect of the lapse of time after exercise and of the intensities of exercise on lipids of rats. Nippon Nogeikagaku Kaishi (J. Agric. Chem. Soc. Jpn.), 50, $17-22$.

7) Fukuda, N., and Sugano, M. (1976): Effect of the combination of exercise and dietary fats on plasma and liver lipids in rats. Nippon Nogeikagaku Kaishi (J. Agric. Chem. Soc. Jpn.), 50, 247-251.

8) Morris, J. N., and Heady, J. A. (1953): Coronary heart-disease and physical activity of work. Lancet, 2, 1111-1120.

9) Leveille, G. A., and Sauberlich, H. F. (1964): Plasma and liver lipids of mice as influenced by dietary protein and sulfur-containing amino acid. J. Nutri., 84, 10-14.

10) Holloszy, J. O. (1967): Biochemical adaptations in muscle. J. Biol. Chem., 242, 2278-2282. 
11) Cleland, K. W., and Slater, E. C. (1953): Respiratory granules of heart muscle. Biochem. J., 53, 547-556.

12) Gornall, A. G., Bardawill, C. J., and David, M. M. (1949): Determination of serum proteins by means of the biuret reaction. J. Biol. Chem., 177, 751-766.

13) Lo, S., Russell, J. C., and TAYloR, A. W. (1970): Determination of glycogen in small tissue samples. J. Appl. Physiol., 28, 234-236.

14) Folch, J., Lees, M., and Sloan-Stanley, G. H. (1957): A simple method for the isolation and purification of total lipids from animal tissues. J. Biol. Chem., 226, 497-509.

15) Kawade, M. (1974): Rinsho Kagaku Bunseki III, Chapter 3, Chusei Shibo, ed. by Niwa, M., Kitamura, M., and Saito, M., Tokyo Kagaku Dojin Co., Ltd., pp. 50-54.

16) NishidA, A. (1969): Analysis of two-way classification data with unequal subclass numbers. Bulletin of the computing centre for research in agriculture forestry and fishery. Series A No. 5, pp. $1-22$.

17) Fuge, K. W., Eugene, L. C., III., Paul, K. P., Holloszy, J. O., and Robert, E. S. (1968): Effects of protein deficiency on certain adaptive responses to exercise. Am. J. Physiol., 215, 660-663.

18) Consolazio, F. C., Johnson, H. L., Nelson, R. A., Dramise, J. G., and Skala, J. H. (1975): Protein metabolism during intensive physical training in the young adult. Am. J. Clin. Nutr., 28, 29-35.

19) SaKamoto, M., Kobayashi, S., Ishit, S., Suzuki, N., and Nishioka, K. (1978): Effect of malnutrition on complement level and tuberclin reactivity in the rats. Eiyo To Shokuryo (J. Jpn. Soc. Food. Nutr.), 31, 49-58.

20) Bergstrom, J., Hermansen, L., Hultman, E., and Saltin, B. (1967): Diet, muscle glycogen and physical performance. Acta Physiol. Scand., 71, 140-150.

21) Karlsson, J., and Saltin, B. (1971): Diet, muscle glycogen, and endurance performance. $J$. Appl. Physiol., 31, 203-206.

22) Ruben, L. (1971): Morphometric study of myocardial mitochondria in the rat. J. Cell. Biol., 48, 673-676.

23) SaKamoto, M., IshiI, S., Kobayashi, S., Suzuki, N., and Nishioka, K. (1978): Effect of malnutrition and nutrition restoration on complement level and tuberculin reactivity in rats. Eiyo To Shokuryo (J. Jpn. Soc. Food. Nutr.), 31, 371-377.

24) Enwonwu, C. O., Stambaugh, R. V., and Jacobson, K. L. (1973): Protein-energy deficiency in nonhuman primates; biochemical and morphological alterations. Am. J. Clin. Nutr., 26, 1287-1302.

25) Hebert, J., Kerkhoff, L., Bell, L., and Lopez-S, A. (1975): Effect of exercise on lipid metabolism of rats fed high carbohydrate diets. J. Nutr., 105, 718-725.

26) Narayan, K. A., Mcmullen, J. J., Butler, D. P., Wakefield, T., and Calhoun, W. K. (1975): Effect of exercise on tissue lipids and serum lipoproteins of rats fed two levels of fat. $J$. Nutr., 105, 581-587.

27) Lopez-S. A., Vial, R., Balart, L., and Arroyave, G. (1974): Effect of exercise and physical fitness on serum lipids and lipoproteins. Atherosclerosis, 20, 1-9.

28) Hori, K., Fujita, S., Sugano, M., and Wada, M. (1973): Dietary factors influencing lecithin: Cholesterol acyltransferase in rat plasma (Part 1). Eiyo To Shokuryo (J. Jpn. Soc. Food. Nutr.), 26, 33-38.

29) Nishida, T., Ueno, A., and Kummerow, F. A. (1960): Effect of dietary protein on the metabolism of sodium acetate-1-C ${ }^{14}$ in chicks. J. Nutr., 71, 379-386.

30) Malinow, M. R., Mclaughlin, P., and Perley, A. (1968): Cholesterol: Treadmill activity accelerates oxidation in rats. Science, 160, 1239-1240.

31) Sugano, M. (1976): Cholesterol metabolism and diets. Eiyo To Shokuryo (J. Jpn. Soc. Food. Nutr.), 29, 253-259.

32) Sugano, M., Hori, K., and Wada, M. (1969): Hepatotoxicity and plasma cholesterol esterification by rats. Arch. Biochem. Biophys., 129, 588-596. 